\title{
CAMPUR KODE BAHASA PENYIAR RADIO SETIAWANA 97,2 FM KECAMATAN ARGAMAKMUR KABUPATEN BENGKULU UTARA
}

\author{
Siska Wulandari, Dian Eka Chandra Wardhana ${ }^{2}$, Ngudining Rahayu ${ }^{3}$ \\ ${ }^{1,2,3}$ Universitas Bengkulu
}

Korespondensi: siskawulandari114@gmail.com

\begin{abstract}
Abstrak
Tujuan penelitian ini untuk mendeskripsikan bentuk campur kode dan mendeskripsikan faktor yang menyebabkan terjadinya campur kode pada penyiar di radio Setiawana 97, 2FM Kecamatan Argamakmur Kabupaten Bengkulu Utara. Metode yang digunakan dalam penelitian ini adalah metode deskriptif. Teknik yang digunakan dalam pengumpulan data di dalam penelitian ini adalah teknik rekam dan teknik wawancara. Langkah-langkah yang dilakukan dalam menganalisis data ada lima tahap yaitu pentranskripsikan data, penyeleksian data, pengklasifikasiandata, penafsiran dan penyimpulan data. Dalam penelitian ini ditemukan adanya bentuk campur kode yang berbentuk kata berupa kata nomina dasar, nomina turunan, verba dasar, verba turunan, ajektiva dasar, numeralia dasar, konjungsi, reduplikasi dan kategori fatis. campur kode yang berbentuk frasa berupa frasa nomina, verba, reduplikasi, ajektiva dan preposisi. Dan campur kode yang berbentuk klausa, serta faktor-faktor yang mempengaruhi terjadinya campur kode pada bahasa yang digunakan oleh penyiar radio pada saat melakukan siaran. Hasil analisis data ditemukan bentuk campur kode yang berasal dari enam bahasa yaitu, BKL, BING, BJW, BPM, BAR, BGR. Bentuk campur kode berupa kata misalnya nak, lagunyo, siapo, request, urung, break, Bentuk campur kode berupa frasa misalnya jugo keksnyo, mintak lagunyo, idak ado, dan bentuk campur kode berupa klausa misalnya request samo kawan kito, punyo mete tapi kalo misalnyo, misalnyo idak ado mete ko. Faktor-faktor yang menyebabkan terjadinya campur kode yakni (1) kebiasaan penutur, (2) pengaruh lingkungan tempat tinggal, (3) konteks situasi agar lebih santai dan akrab dengan pendengar, (4) menggunakan istilah yang lebih populer agar terlihat lebih keren, (5) untuk membangkitkan rasa humor, dan (6) latar belakang suku / asal penutur.
\end{abstract}

Kata kunci: campur kode, bahasa, penyiar, radio setiawana 97,2 FM

\section{Abstract}

This study aimed to described the meaning the form of code mixing and to describe the factors that cause code mixing in broadcasters on radio Setiawana 97, 2FM, Argamakmur District, Bengkulu Utara Regency. The method used in this research is descriptive method. The techniques used in data collection in this study were recording techniques and interview techniques. There are five steps taken in analyzing the data, namely data transcription, data selection, data classification, interpretation and data conclusion. In this study, it was found that there were mixed code forms in the form of words in the form of basic nouns, derived nouns, basic verbs, derivative verbs, basic adjectives, basic numeralia, conjunctions, reduplications and phatic categories. Mix code in the form of phrases in the form of noun, verbs, reduplications, adjectives and prepositions. And mix code in the form of clauses, as well as the factors that influence the occurrence of code mixing in the language used by radio broadcasters when broadcasting. The results of data analysis found a form of mixed code originating from six languages, namely, $B K L, B I N G, B J W, B P M, B A R, B G R$. The form of 
mixed code is in the form of words, for example want, the song, who, request, not yet, break, The mixed code form is in the form of a phrase, for example the keks, ask for the song, does not exist, and the code mixed form is in the form of clauses, for example request with our friends, have a boyfriend, but if for example For example, there is no girlfriend. The factors that cause code mixing are (1) the habits of the speakers, (2) the influence of the environment in which they live, (3) the context of the situation to make it more relaxed and familiar with listeners, (4) using more popular terms to make it look cooler, (5) to evoke a sense of humor, and (6) the ethnic background / origin of the speakers.

Keywords: code mix, language, announcer, radio setiawana 97.2FM

\section{PENDAHULUAN}

Sosiolingustik merupakan gabungan duailmu disiplin yang menggabungkan sosiologi dan linguistik, dua bidang ilmu empiris yang mempunyai kaitan yang sangat erat. Sosiologi adalah kajian yang objektif dan ilmiah mengenai manusia di dalam masyarakat, mengenai lembaga-lembaga, dan proses sosial yang ada di dalam masyarakat, sedangkan linguistik adalah bidang ilmu yang mempelajari bahasa, atau bidang ilmu yang mengambil bahasa sebagai objek kajiannya. Dengan demikian, dapat dikatakan bahwa sosiolinguistik adalah bidang ilmu antardisiplin yang mempelajari bahasa dalam kaitannya dengan penggunaan bahasa di dalam masyarakat. Oleh karena itu, bagaimanapun rumusan mengenai sosiolinguistik tidak akan terlepas dari persoalan hubungan bahasa dengan kegiatan-kegiatan atau aspek-aspek kemasyarakatan (Chaer dan Agustina ,2014: 2).

Bram dan Dickey dalam Rokhman (2013:2) menyatakan bahwa sosiolinguistik khusus mengkaji fungsi bahasa di masyarakat. Dalam penggunaannya di masyarakat sosiolinguistik menjelaskan kemampuan manusia menggunakan aturan-aturan berbahasa secara tepat dalam situasi-situasi.

Dalam sosiolinguistik bahasa adalah alat atau berfungsi untuk menyampaikan pikiran dianggap terlalu sempit, sebab seperti dikemukakan Fishman dalam Chaer dan Agustina (2014: 15) mengatakan bahwa yang menjadi persoalan sosiolingusitik adalah "who speak what language to whom", when and to what end.Peristiwa tutur dapat terjadi apabila ada dua orang atau lebih sedang dalam percakapan atau konteks tertentu di tempat dan waktu yang sama dan menggunakan bahasa yang sama-sama mereka kuasai untuk memudahkan mereka dalam melakukan komunikasi. Di dalam komunikasi, tidak ada tuturan tanpa situasi tutur (pokok pembicaraan).

Hymes dalam Chaer dan Agustina (2014: 48-49), menyatakan bahwa suatu peristiwa tutur harus memenuhi kedelapan komponen, yaitu bila huruf-huruf pertamanya dirangkaikan menjadi akronim SPEAKING. Kedelapan komponen itu adalah (diangkat dari Wadhaugh 1990).Penggunaan bahasa di masyarakat menimbulkan banyaknya variasi bahasa yang terjadi. Variasi bahasa terjadi berdasarkan kesadaran penutur dalam melakukan tindak tutur dan menjadikan variasi bahasa sebagai salah satu faktor yang menjadikan penutur dapat berbaur dengan situasi dan maksud tujuan pembicaran pada situasi tertentu. Misalnya variasi bahasa pada saat penyiar radio melakukan siaran radio, tentu saja penyiar radio tersebut akan melakukan ragam bahasa jurnalistik. Ragam bahasa jurnalistik mempunyai ciri bersifat sederhana, komunikatif dan ringkas (Chaer dan Agustina,2014: 69).

Bilingualisme adalah suatu fenomena kebahasaan yang dapat diamati di seluruh dunia. Banyak negara di dunia yang memiliki penutur yang menguasai lebih dari satu bahasa. Ratusan juta orang di dunia rutin menggunakan dua, tiga atau bahkan empat 
bahasa dalam kehidupan sehari-hari mereka. Bahkan, penutur monolingual pun juga rutin beralih kode dari satu variasi bahasa ke variasi lain misalnya dari Dialek regional ke bahasa standar, dengan menggunakan laras teknis tertentu, gaya formal atau informal, dan sebagainya dalam interaksi sehari-hari mereka (Lapasau dan Arifin,2016: 95).

Indonesia kaya akan budaya dan bahasa. Bahasa indonesia terdiri dari beribu-ribu bahasa daerah. Hal tersebut menjadi salah satu faktor terjadinya kedwibahasaan dalam lingkungan sosial. Kedwibahasaan tersebut bukan tidak mungkin terjadi jika melihat situasi jaman sekarang. Hampir semua masyarakat menggunakan dua bahasa bahkan lebih dalam bersosialisasi dalam lingkungan masyarakat.

Fenomena dwibahasa atau bilingualisme dapat terjadi kapan saja dan dimana saja yang dialami oleh individu pengguna bahasa. Fenomena bilingualisme dapat terjadi pada kalangan anak-anak, remaja, maupun dewasa. Hal tersebut dapat terjadi di sekolah, di rumah, di lingkungan tempat tinggal maupun di tempat-tempat lainnya. Hal ini dikarenakan kebiasaan penutur dan lawan tutur dalam berkomunikasi menggunakan dua bahasa atau lebih dan menyebabkan terjadinya campur kode pada tuturan mereka. Sehingga peristiwa kedwibahasaan ini menjadi sesuatu hal yang biasa terjai dalam kehidupan sehari-hari.

Nababan dalam Suandi (2014: 139) mengungkapkan bahwa campur kode adalah pencampuran dua atau lebih bahasa atau ragam bahasa dalam suatu tindak bahasa (speech act atau discourse) tanpa ada sesuatu dalam situasi berbahasa itu yang menuntut pencampuran bahasa itu.Senada dengan pandangan Nababan tersebut M.Thelander dalam artikelnya dengan judul "Code Switching or Code Mixing (1976)" mengemukakan bahwa yang dimaksud dengan campur kode adalah pencampuran atau kombinasi antara variasi-variasi yang berbeda di dalam satu klausa yang berbeda di dalam satu klausa buster (bybrid clauses) (Suandi, 2014:139).Bentuk Campur Kode :

1. Penyisipan Unsur-Unsur Yang Berbentuk Kata

Kridalaksana dalam Muslich (2010: 118-121) mengelompokkan kata ke dalam 13 golongan yaitu, Verba, Ajektiva, Nomina, Pronomina, Numeralia, Adverbia, Interogativa, Demonstrativa, Artikula, Preposisi, Konjungsi, Interjeksi, dan Kategori Fatis.

2. Penyisipan Unsur-Unsur yang Berbentuk Frasa

Menurut Chaer (2009: 120) frase adalah satuan sintaksis yang tersusun dari dua buah kata atau lebih, yang di dalam klausa menduduki fungi-fungsi sintaksis.

3. Penyisipan Unsur-Unsur yang Berbentuk Klausa

Menurut M Ramlan (2005: 79), klausa adalah satuan gramtik yang terdiri dari S, $P$ baik disertai O, PEL, KET ataupun tidak. Dengam ringkas klausa ialah

S P (O) (PEL) (KET). Tanda kurung menandakan bahwa apa yang terletak dalam kurung itu bersifat manasuka, artinya boleh ada dan boleh juga tidak ada.

Menurut Prof.Dr. I Nengah Suandi M. Hum (2014: 143-146) Campur kode disebabkan oleh beberapa faktor berikut yaitu:

1. keterbatasan Penggunaan Kode

2. Penggunaan Istilah yang Lebih

Populer

3. Pembicara dan Pribadi Pembicara

4. Mitra Bicara
5. Tempat Tinggal dan Pembicaraan Berlangsung

6. Modus Pembicaraan

7. Topik

8. Fungsi dan Tujuan

9. Ragam dan Tingkat Tutur Bahasa 
10. Hadirnya penutur ketiga

11. Pokok Pembicara
12.Untuk Membangkitkan Rasa Humor

13. Untuk Sekadar Bergengsi

Fenomena campur kode yang terjadi di lingkungan masyarakat tutur memungkinkn akan terjadi alih kode.Apple dalam Chaer dan Agustiana (2014: 107) mendefinisikan alih kode sebagai, "gejala peralihan pemakaian bahasa karena berubahnya situasi”. Dengan demikian, alih kode itu merupakan gejala peralihan pemakaian bahasa yang terjadi karena situasi dan terjadi antar bahasa serta antar ragam dalam satu bahasa.

Secara luas, istilah "alih kode" mengacu pada penjajaran elemen dari dua ( atau lebih ) bahasa taua dialek. Namun, ada sedikit kesepakan di antara para sarjana tentang lingkup semantik dari istilah yang mereka gunakan, atau sifat perbedaan yang dapat ditarik diantara itu dan lainnya, istilah terkait seperti diglosia, pergeseran

Menurut Fishman dalam Chaer dan Agustina (2014: 108-110), faktor yang mempengaruhi alih kode yaitu (1) pembicara atau penutur, (2) pendengar atau lawan tutur, (3) perubahan situasi dengan hadirnya orang ketiga, (4) perubahan dari formal ke informal atau sebaliknya, (5) perubahan topik pembicaraan.

\section{METODE}

Metode penelitian yang digunakan dalam penelitian ini adalah metode deskriptif. Penelitian deskriptif bertujuan untuk mendeskripsikan apa-apa saja yang saat ini berlaku. Didalamnya terdapat upaya mendeskripsikan, mecatat, menganalisa dan menginterpretasikan kondisi-kondisi sekarang ini terjadi. Deskriptif merupakan gambaran ciri-ciri data secara akurat sesuai dengan sifat alamiah itu sendiri (Djadjasudarma, 1993: 16).

Penelitian ini dilakukan di Radio Setiawana 97,2 FM yang terletak di Jl. Husni Thamrin No. 12 Arga Makmur Bengkulu Utara.

Sumber data dalam penelitian ini adalah tuturan atau wacana penyiar radio yang sedang melakukan siaran radio.

Data dalam penelitian ini adalah yang mengandung campur kode yang berbentuk kata, frasa dan klausa. Penelitian ini difokuskan pada satu acara yaitu asiknya dangdut yang di siarakan setiap hari senin sampai minggu oleh Elvira.

Teknik yang digunakan untuk pengumpulan data teknik rekam dan teknik wawancara. Teknik rekam digunakan pada saat ingin mengambil data bentuk campur kode dan teknik wawancara digunakan pada saat ingin mengambil data mengenai faktor campur kode.

Langkah-langkah analisis data dalam penelitian ini dilakukan dengan berbagai cara yaitu :

1. Mentranskripsikan Data

Data yang sudah terkumpul kemudian ditranskripsikan dengan cara ditulis berdasarkan hasil rekaman yang sudah dilakukan. Transkripsi yang dimaksud adalah memindahkan dari bahasa lisan ke dalam bentuk tulisan.

2. Identifikasi Data

Data yang dikumpulkan selanjutnya identifikasi, dicatat sesuai dengan kebutuhan.

Dalam penelitian ini data yang akan diambil berupa bentuk campur kode yang terjadi pada saat penyiar radio melakukan siaran radio.

3. Klasifikasi Data 
Data yang sudah ditranskripsikan dan diseleksi kemudian di klasifikasikan ke dalam bentuk campur kode menurut teori Khairah dan Ridwan (2014: 21). yaitubentuk campur kode yang bisa berbentuk kata, frasa, dan klausadan faktor campur kode. Data yang telah diperoleh akan dimasukkan ke dalam bentuk-bentuk campur kode dan faktor penyebab terjadinya campur kode tersebut.

4. Penjelasan Data

Data yang sudah dikelompokkan dalam bentuk campur kode tersebut, kemudian dianalisis secara rinci dan data ditafsirkan serta dilakukan penjelasan mengenai data tersebut.

5. Simpulan

Sebelum penulis menyimpulkan bentuk-bentuk campur kode dan faktor penyebab campur kode berdasarka data yang di dapat, maka terlebih dahulu penulis akan mewawancarai penutur untuk mendapatkan keterangan mengenai faktor yang menyebabkan terjadinya campur kode

\section{HASIL}

Hasil penelitian ini adalah ditemukan adanya bentuk campur kode yang berbentuk kata berupa kata nomina dasar, nomina turunan, verba dasar, verba turunan, ajektiva dasar, numeralia dasar, konjungsi, reduplikasi dan kategori fatis. campur kode yang berbentuk frasa berupa frasa nomina, verba, reduplikasi, ajektiva dan preposisi. Dan campur kode yang berbentuk klausa, serta faktor-faktor yang mempengaruhi terjadinya campur kode pada bahasa yang digunakan oleh penyiar radio pada saat melakukan siaran.

Bentuk campur kode yang ditemukan adalah: (a) campur kode bahasa Melayu Bengkulu ke dalam bahasa Indonesia, (b) campur kode bahasa Inggris ke dalam bahasa Indonesia, (c) campur kode bahasa Sumatera Selatan kedalam bahasa Indonesia, (d) campur kode bahasa Arab ke dalam bahasa Indonesia, (e) campur kode bahasa Jawa ke dalam bahasa Indonesia, dan (f) campur kode bahasa gaul ke dalam bahasa Indonesia. Bentuk campur kode tersebut meliputi : (a) unsur yang berbentuk kata, (b) unsur yang berbentuk frasa, (c) unsur yang berbentuk klausa. Selain bentuk campur kode, juga di temukan faktor yang mempengaruhi terjadinya campur kode.

Adapun faktor-faktor yang menyebabkan terjadinya Campur kode pada bahasa yang digunakan oleh penyiar radio Setiawana 97,2 FM adalah: (a) faktor kebiasaan, (b) faktor lingkungan tempat tinggal, (c) faktor fungsi dan tujuan, (d) faktor supaya terkesan santai dan akrab dengan pendengar, (e) faktor menggunakan istilah yang lebih populer, (f) untuk membangkitkan rasa humor, dan (g) faktor kebahasaan.

\section{PEMBAHASAN}

A.Bentuk Campur Kode bahasa penyiar radio setiawana 97,2FM

1. Campur Kode Berupa Kata

Kata adalah satuan bahasa terkeil yang dapat berdiri sendiri. Berikut penulis akan menguraikan beberapa bentuk campur kode yang berupa kata dalam bahasa yang digunakan oleh penyiar radio.

\begin{tabular}{|c|c|c|c|c|c|c|}
\hline NO & BKL & BING & BPM & BJW & BAR & BGL \\
\hline 1 & $\begin{array}{l}\text { caronyo } \\
\text { (nomina } \\
\text { turunan) }\end{array}$ & $\begin{array}{l}\text { request } \\
\text { (verba } \\
\text { dasar) }\end{array}$ & $\begin{array}{l}\text { Gek } \\
\text { (nomin }\end{array}$ & $\begin{array}{l}\text { Urung } \\
\text { (verba } \\
\text { dasar) }\end{array}$ & $\begin{array}{l}\text { assalamu'alai } \\
\text { kum } \\
\text { warrabmatull }\end{array}$ & $\begin{array}{l}\text { Syantik } \\
\text { (adjektiva } \\
\text { dasar) }\end{array}$ \\
\hline
\end{tabular}




\begin{tabular}{|c|c|c|c|c|c|c|}
\hline NO & BKL & BING & BPM & BJW & BAR & BGL \\
\hline & & & $\begin{array}{l}a \\
\text { dasar) }\end{array}$ & & $\begin{array}{l}\text { abhiwabarak } \\
\text { atuh (kategori } \\
\text { fatis) }\end{array}$ & \\
\hline 2 & $\begin{array}{l}\text { nak } \\
\text { (nomina } \\
\text { dasar) }\end{array}$ & $\begin{array}{l}\text { break (verba } \\
\text { dasar) }\end{array}$ & $\begin{array}{l}\text { Kagek } \\
\text { (konju } \\
\text { ngsi) }\end{array}$ & & & $\begin{array}{l}\text { Curcol } \\
\text { (verba } \\
\text { dasar) }\end{array}$ \\
\hline 3 & $\begin{array}{l}\text { samo-samo } \\
\text { (reduplikasi) }\end{array}$ & $\begin{array}{l}\text { play (verba } \\
\text { dasar) }\end{array}$ & & & & \\
\hline 4 & $\begin{array}{l}\text { lagunyo } \\
\text { (nomina) }\end{array}$ & $\begin{array}{l}\text { follow } \\
\text { (nomina } \\
\text { dasar) }\end{array}$ & & & & \\
\hline 5 & $\begin{array}{l}\text { selanjutnyo( } \\
\text { konjungsi) }\end{array}$ & $\begin{array}{l}\text { chatting(nom } \\
\text { ina dasar) }\end{array}$ & & & & \\
\hline 6 & $\begin{array}{l}\text { siapo } \\
\text { (nomina } \\
\text { dasar) }\end{array}$ & $\begin{array}{l}\text { requestannyo } \\
\text { yo }\end{array}$ & & & & \\
\hline 7 & $\begin{array}{l}\text { ajo (nomina } \\
\text { dasar) }\end{array}$ & $\begin{array}{l}\text { request- } \\
\text { request } \\
\text { (reduplikasi) }\end{array}$ & & & & \\
\hline 8 & $\begin{array}{l}\text { kito } \\
\text { (nomina } \\
\text { dasar) }\end{array}$ & $\begin{array}{l}\text { request.an } \\
\text { (verba } \\
\text { turunan) }\end{array}$ & & & & \\
\hline 9 & $\begin{array}{l}\text { lupo } \\
\text { (ajektiva } \\
\text { dasar) }\end{array}$ & & & & & \\
\hline 10 & $\begin{array}{l}\text { ko (nomina } \\
\text { dasar) }\end{array}$ & & & & & \\
\hline 11 & $\begin{array}{l}\text { keek } \\
\text { (konjungsi) }\end{array}$ & & & & & \\
\hline 12 & $\begin{array}{l}\text { jugo } \\
\text { (konjungsi) }\end{array}$ & & & & & \\
\hline 13 & $\begin{array}{l}\text { nyo (nomina } \\
\text { dasar) }\end{array}$ & & & & & \\
\hline 14 & $\begin{array}{l}\text { keluargo } \\
\text { (nomina } \\
\text { dasar) }\end{array}$ & & & & & \\
\hline 15 & $\begin{array}{l}\text { yo } \\
\text { (konjungsi) }\end{array}$ & & & & & \\
\hline 16 & kato & & & & & \\
\hline 17 & ado & & & & & \\
\hline 18 & $\begin{array}{l}\text { pastinyo } \\
\text { (verba } \\
\text { turunan) }\end{array}$ & & & & & \\
\hline 19 & $\begin{array}{l}\text { samo (verba } \\
\text { dasar) }\end{array}$ & & & & & \\
\hline
\end{tabular}




\begin{tabular}{|l|l|l|l|l|l|l|}
\hline NO & \multicolumn{1}{|c|}{ BKL } & BING & BPM & BJW & BAR & BGL \\
\hline 20 & $\begin{array}{l}\text { duo } \\
\text { (numeralia } \\
\text { dasar) }\end{array}$ & & & & & \\
\hline 21 & $\begin{array}{l}\text { terbarunyo } \\
\text { (ajektiva } \\
\text { dasar) }\end{array}$ & & & & & \\
\hline 22 & $\begin{array}{l}\text { mintak } \\
\text { lagunyo }\end{array}$ & & & & & \\
\hline 23 & $\begin{array}{l}\text { duo tigo } \\
\text { (numeralia } \\
\text { dasar) } \\
\text { nyo yo }\end{array}$ & & & & & \\
\hline 24 & & & & & \\
\hline
\end{tabular}

\section{(1)(II/01/02/20/CK/BING)}

Konteks : Acara Asiknya Dangdut Edisi 1 Februari 2020, Siaran radio Asiknya Dangdut ini berlangsung pada hari senin sampai hari minggu. pukul 15.00WIB 16.30WIB dengan tema bedah lagu dangdut terbaru dan memberi informasi kepada pendengar yang ingin me-request lagu. Penyiar radio yaitu Elvira yang menggunakan Bahasa Indonesia dan memasukkan unsur Bahasa Inggris pada saat melakukan siaran.

"Balik lagi sahabat masih sama Vira di asiknya dangdut. Nah kini buat sahabat yang masih mau request ataupun yang mau kirim-kirim salamboleh banget langsung gabungan bareng Vira di sore hari ini”.

Data (1)(II/01/02/20/CK/BING)di atas terdapat campur kode yang berbentuk kata dari bahasa asing, yakni penyisipan kata bahasa Inggris kedalam bahasa Indonesia. yang berupa kata verba dasar. Kata request yang digunakan oleh penyiar berarti 'meminta'. Data tersebut dalam padanan bahasa Indonesia menjadi

"Kembali lagi sahabat, masih sama Vira di asiknya dangdut, nah sekarang untuk sahabat yang masih mau kirim lagu atau pun yang mau kirim-kirim salam boleh banget langsung gabungan bareng Vira di sore hari ini”.

\section{Campur Kode Berupa Frasa}

Menurut Chaer (2009: 120) frase adalah satuan sintaksis yang tersusun dari dua buah kata atau lebih, yang di dalam klausa menduduki fungi-fungsi sintaksis.Berikut penulis akan menguraikan beberapa bentuk campur kode yang berupa frasa dalam bahasa yang digunakan oleh penyiar radio.

\begin{tabular}{|c|c|c|c|c|c|c|}
\hline No & BKL & BING & BPM & BJW & BAR & BGL \\
\hline 1 & $\begin{array}{l}\text { jugo keksnyo } \\
\text { (nomina) }\end{array}$ & $\begin{array}{l}\text { stay tune } \\
\text { (verba) }\end{array}$ & & & & \\
\hline 2 & $\begin{array}{l}\text { dakpapo yo } \\
\text { (verba) }\end{array}$ & & & & & \\
\hline
\end{tabular}




\begin{tabular}{|c|c|c|c|c|c|c|}
\hline No & BKL & BING & BPM & BJW & BAR & BGL \\
\hline 3 & $\begin{array}{l}\text { idak ado } \\
\text { (ajektiva) }\end{array}$ & & & & & \\
\hline 4 & $\begin{array}{l}\text { pokoknyo } \\
\text { caronyo } \\
\text { (nomina) }\end{array}$ & & & & & \\
\hline 5 & kalo misalnyo & & & & & \\
\hline 6 & $\begin{array}{l}\text { lamo caronyo } \\
\text { (nomina) }\end{array}$ & & & & & \\
\hline 7 & $\begin{array}{l}\text { dak ado } \\
\text { (ajektiva) }\end{array}$ & & & & & \\
\hline 8 & $\begin{array}{l}\text { di mano bae } \\
\text { (preposisi) }\end{array}$ & & & & & \\
\hline 9 & $\begin{array}{l}\text { gabungan kek } \\
\text { (verba) }\end{array}$ & & & & & \\
\hline 10 & $\begin{array}{l}\text { Langsung ajo } \\
\text { (verba) }\end{array}$ & & & & & \\
\hline
\end{tabular}

\section{(1)(II/1/02/20/CK/BKL)}

Konteks : Acara Asiknya Dangdut edisi 01 Februari 2020, Siaran radio Asiknya Dangdut ini berlangsung pada hari senin-minggu pukul 15.00WIB - 16.30WIB dengan tema bedah lagu dangdut terbaru dan menjelaskan cara me-request lagu. Penyiar radio yaitu Elvira yang menggunakan Bahasa Indonesia dan memasukkan unsur bahasa Melayu Bengkulu pada saat melakukan siaran

"Caronyo gampang nian,ketik asiknya dangdut spasi nama alamat request dan jugokks-nyo."

Pada Data (1)(II/1/02/20/CK/BKL) di atas terdapat campur kode yang berbentukfrase daribahasa Melayu Bengkulu, yakni penyisipan bahasa Melayu Bengkulu ke dalam bahasa Indonesia. Frase adalah satuan gramatik yang terdiri dari dua kata atau lebih.Frasa jugo $\boldsymbol{k} \boldsymbol{k s}$-nyo berarti 'juga kks-nya', merupakan frase nomina, yaitu frase yang nominal yang diikuti keterangan.Data tersebut padanan dalam bahasa Indonesia menjadi

"Caranya mudah sekali ketik asiknya dangdut spasi nama alamat kirim lagu dan juga kirim-kirim salamnya"

\section{Campur Kode Berupa Klausa}

Menurut M Ramlan (2005: 79), klausa adalah satuan gramtik yang terdiri dari S, $\mathrm{P}$ baik disertai $\mathrm{O}$, PEL, KET ataupun tidak. Dengam ringkas klausa ialah S P (O) (PEL) (KET). Tanda kurung menandakan bahwa apa yang terletak dalam kurung itu bersifat manasuka, artinya boleh ada dan boleh juga tidak ada.Berikut penulis akan menguraikan bentuk campur kode berupa klausa bahasa yang digunakan oleh penyiar radio setiawana 97,2FM.

\begin{tabular}{|c|l|l|l|l|l|l|}
\hline No & \multicolumn{1}{|c|}{$\boldsymbol{B K \boldsymbol { L }}$} & $\boldsymbol{B I N G}$ & $\boldsymbol{B P M}$ & $\boldsymbol{B J W}$ & $\boldsymbol{B} \boldsymbol{A} \boldsymbol{R}$ & $\boldsymbol{B} \boldsymbol{G L}$ \\
\hline $\mathbf{1}$ & $\begin{array}{l}\text { Vira nak } \\
\text { bacoin }\end{array}$ & $\begin{array}{l}\text { Vira nak } \\
\text { bacoin }\end{array}$ & & & & $\begin{array}{l}\text { curcol } \\
\text { manja } \\
\text { laila }\end{array}$ \\
\hline
\end{tabular}




\begin{tabular}{|c|c|c|c|c|c|c|}
\hline No & $B K L$ & $B I N G$ & $B P M$ & $B J W$ & $B A R$ & $B G L$ \\
\hline & $\begin{array}{l}\text { request.an di via } \\
\text { SMS }\end{array}$ & $\begin{array}{l}\text { request.an di } \\
\text { via SMS }\end{array}$ & & & & \\
\hline 2 & nyo dak ado ko & $\begin{array}{l}\text { request samo } \\
\text { kawan kito }\end{array}$ & & & & \\
\hline 3 & $\begin{array}{l}\text { request samo } \\
\text { kawan kito }\end{array}$ & $\begin{array}{l}\text { request keke } \\
\text { keks-nyo } \\
\text { kirim-kirim } \\
\text { salam nyo }\end{array}$ & & & & \\
\hline 4 & $\begin{array}{l}\text { punyo mete tapi } \\
\text { kalo misalnyo }\end{array}$ & $\begin{array}{l}\text { follback } \\
\text { kelak yo }\end{array}$ & & & & \\
\hline 5 & $\begin{array}{l}\text { misalnyo idak } \\
\text { ado mete ko }\end{array}$ & $\begin{array}{l}\text { request kek } \\
\text { kks-nyo }\end{array}$ & & & & \\
\hline 6 & $\begin{array}{l}\text { dak ado pulsa } \\
\text { cakmano vira } \\
\text { ndak } \\
\text { gabungannyo }\end{array}$ & check this on & & & & \\
\hline 7 & $\begin{array}{l}\text { pulsanyo maso } \\
\text { vira pulo yang } \\
\text { ndak belikan } \\
\text { iyo dak. }\end{array}$ & $\begin{array}{l}\text { salamnyo } \\
\text { kito break }\end{array}$ & & & & \\
\hline 8 & $\begin{array}{l}\text { request keke } \\
\text { keks-nyo kirim- } \\
\text { kirim salam nyo }\end{array}$ & & & & & \\
\hline 9 & $\begin{array}{l}\text { kito tu gampang } \\
\text { nian nyarinyo }\end{array}$ & & & & & \\
\hline 10 & $\begin{array}{l}\text { follback kelak } \\
\text { yo }\end{array}$ & & & & & \\
\hline 11 & $\begin{array}{l}\text { pado dak ado } \\
\text { gawean }\end{array}$ & & & & & \\
\hline 12 & $\begin{array}{l}\text { kek Vira disore } \\
\text { bariko caronyo } \\
\text { gampang nian } \\
\text { ko yo sababat yo }\end{array}$ & & & & & \\
\hline 13 & $\begin{array}{l}\text { limo tigo duo } \\
\text { satu satu enam } \\
\text { duo }\end{array}$ & & & & & \\
\hline 14 & $\begin{array}{l}\text { request keek } \\
\text { keks-nyo }\end{array}$ & & & & & \\
\hline 15 & $\begin{array}{l}\text { di mano pun } \\
\text { berado di mano } \\
\text { pun berado yuk } \\
\text { sanak keluargo } \\
\text { boleh gabung } \\
\text { kek Vira }\end{array}$ & & & & & \\
\hline
\end{tabular}




\begin{tabular}{|c|c|c|c|c|c|c|}
\hline No & $B K L$ & $B I N G$ & $B P M$ & $B J W$ & $B A R$ & $B G L$ \\
\hline & $\begin{array}{l}\text { hariko kita } \\
\text { seru-seruan } \\
\text { samo-samo yo } \\
\text { kan dari pada } \\
\text { pening palak ko } \\
\text { dak tau nak } \\
\text { ngapo }\end{array}$ & & & & & \\
\hline 16 & $\begin{array}{l}\text { nak kemano } \\
\text { dak ado kawan } \\
\text { ndak. }\end{array}$ & & & & & \\
\hline 17 & $\begin{array}{l}\text { yo sanak } \\
\text { saudara yang di } \\
\text { mano bae ko di } \\
\text { mano berado }\end{array}$ & & & & & \\
\hline 18 & $\begin{array}{l}\text { kek kawan- } \\
\text { kawannyo } \\
\text { sahabatnyo kek } \\
\text { gebetannyo kalo } \\
\text { punyo apo lagi } \\
\text { yang punyo mete } \\
\text { boleh nian } \\
\text { gabungan bareng } \\
\text { Vira di sore } \\
\text { hari iko yo }\end{array}$ & & & & & \\
\hline 19 & $\begin{array}{l}\text { request.an kek } \\
\text { kes nyo }\end{array}$ & & & & & \\
\hline 20 & $\begin{array}{l}\text { salamnyo kito } \\
\text { break. }\end{array}$ & & & & & \\
\hline 21 & $\begin{array}{l}\text { keluargo untuk } \\
\text { sababatnyo } \\
\text { kawannyo yo } \\
\text { ataupun untuk } \\
\text { gebetannyo } \\
\text { metenyo } \\
\text { mungkin yo }\end{array}$ & & & & & \\
\hline
\end{tabular}

(1)(II/01/02/20/BKL-BING)

Konteks : Acara Asiknya Dangdut edisi 1 februari 2020, Siaran radio Asiknya Dangdut ini berlangsung pada hari senin-minggu pukul 15.00WIB - 16.30WIB dengan tema bedah lagu dangdut terbaru dan penyiar yang menjelasakan cara me request lagu dan membacakan request.an via SMS. Penyiar radio yaitu Elvira yang menggunakan Bahasa Indonesia dan memasukkan unsur bahasa Melayu Bengkulu dan bahasa Inggris pada saat melakukan siaran

"Balik lagi sahabat, masih sama Vira di asiknya dangdut. nah kini buat sahabat yang masih mau request ataupun yang mau kirim-kirim salam,boleh banget langsung 
gabungan bareng Vira di sore hari ini. Caronyo gampang nian, ketik asiknya dangdut spasi nama alamat request dan jugo kksnyo. jangan lupo buat penyanyi dan juga judul lagunya ya sahabat ya.oke dan langsung ajaVira nak bacoin requestandi via SMS sahabat ya".

Pada Data(1)(II/01/02/20/BKL-BING) di atas terdapat campur kode yang berbentuk klausa dari bahasa Melayu Bengkulu dan bahasa asing, yakni penyisipan klausa bahasa Melayu Bengkulu dan bahasa Inggris ke dalam tuturan bahasa Indonesia. Klausa adalah satuan gramatik yang terdiri dari S, P baik disertai O, PEL, KET atau tidak. Klausa Viranak bacoin requestan merupakan klausa verba tindakan bersasaran tak berpelengkap, yang memiliki fungsi sintaksis S, P, dan O.yang digunakan oleh penyiar radio dalam cuplikan di atas berarti 'Vira ingin bacakan permintaan'. Data tersebut padanan dalam bahasa Indonesia menjadi

"Balik lagi sahabat, masih sama Vira di asiknya dangdut .nah kini buat sahabat yang masih mau minta lagu ataupun yang mau kirim-kirim salam,boleh banget langsung gabungan bareng Vira di sore hari ini. caranya gampang nian, ketik asiknya dangdut spasi nama alamat permintaan dan juga kirim-kirim salamnya. jangan lupa buat penyanyi dan juga judul lagunya ya sahabat ya.okedan langsung aja Vira ingin bacakan permintaan di via SMS sahabat ya".

B. Faktor Penyebab Terjadinya Campur Kode Penyiar Radio Setiawana 97,2FM Menutur Suandi (2014:143) sebab-sebab terjadinya gejala campur kode ada beberapa hal, yaitu: keterbatasan penggunaan kode, penggunaan istilah yang lebih populer, pembicara dan pribadi pembicara, mitra bicara, tempat dan waktu pembicaraan berlangsung, modus pembicaraan, topik, fungsi dan tujuan, dan terakhir ragam dan tingkat tutur bahasa. Berikut contoh analisis salah satu faktor penyebab campur kode (1/II) 01/02/20/CK/BING

Konteks : Acara Asiknya Dangdut Edisi 1 Februari 2020, Siaran radio Asiknya Dangdut ini berlangsung pada hari senin sampai hari minggu. pukul 15.00WIB 16.30WIB dengan tema bedah lagu dangdut terbaru dan memberi informasi kepada pendengar yang ingin me-request lagu. Penyiar radio yaitu Elvira yang menggunakan Bahasa Indonesia dan memasukkan unsur Bahasa Inggris pada saat melakukan siaran.

“Balik lagi sahabat masih sama Vira di asiknya dangdut. Nah kini buat sahabat yang masih mau request ataupun yang mau kirim-kirim salamboleh banget langsung gabungan bareng Vira di sore hari ini”.

Pada Data (1/II) 01/02/20/II/CK/BING di atas dapat dilihat proses pembentukan campur kode yang berbentuk kata dalam bahasa asing, yakni penyisipan kata bahasa Inggris kedalam bahasa Indonesia. Kata request yang digunakan oleh penyiar berarti 'meminta'. Campur kode yang dilakukan oleh penyiar radio dilatarbelakangi oleh faktor penggunaan istilah yang lebih populer di masyarakat. Masyarakat terbiasa menggunakan kata request. Sehingga masyarakat lebih mudah memahami informasi yang disampaikan penyiar radio. Campur kode yang dilakukan oleh penyiar radio dilatarbelakangi oleh faktor penggunaan istilah yang lebih populer. 


\section{PENUTUP}

\section{Simpulan}

Berdasarkan hasil penelitian dan pembahasan yang telah dilakukan, bentuk campur kode bahasa penyiar radio setiawana 97,2FM meliputi (a) unsur yang berbentuk kata berupa kata nomina dasar, nomina turunan, verba dasar, verba turunan, ajektiva dasar, numeralia dasar, konjungsi, reduplikasi dan kategori fatis., (b) unsur yang berbentuk frasa berupa frasa nomina, frasa verba, frasa reduplikasi, frasa ajektiva dan frasa preposisi dan (c) unsur yang berbentuk klausa. Campur kode tersebut meliputi penyisipan bahasa Inggris ke dalam tuturan Indonesia, penyisipan Melayu Bengkulu kedalam tuturan bahasa Indonesia, penyisipan bahasa Sumatera Selatan ke dalam bahasa Indonesia, penyisipan bahasa Jawa ke dalam bahasa Indonesia, penyisipan bahasa Arab ke dalam bahasa Indonesia dan penyisipan bahasa gaul ke dalam bahasa Indonesia.

Faktor-faktor penyebab terjadinya campur kode bahasa penyiar radio setiawana 97,2 FM meliputi (a) faktor kebiasaan, (b) faktor lingkungan tempat tinggal, (c) faktor fungsi dan tujuan, (d) faktor supaya terkesan santai dan akrab dengan pendengar, (e) faktor menggunakan istilah yang lebih populer, (f) untuk membangkitkan rasa humor, dan (g) faktor kebahasaan.

\section{Saran}

Setelah meneliti tentang Campur Kode Bahasa Penyiar Radio Setiawana 97,2 FM Kecamatan Argamakmur Kabupaten Bengkulu Utara, penulis memberikan saran sebagai berikut :

Penelitian yang dilakukan penulis terbatas pada bentuk-bentuk dan faktor faktor campur kode yang terdapat dalam tuturan pada acara Asiknya Dangdut di Radio Setiawana 97,2 FMArgamakmur. sudah ada penelitian mengenai campur kode, namun masih sedikit ragam bahasa yang digunakan oleh penyiar radio. Oleh sebab itu, penulis menyarankan agar penelitian selanjutnya meneliti mengenai alih kode dan ragam bahasa yang digunakan oleh penyiar radio.

\section{DAFTAR PUSTAKA}

Chaer, Abdul dan Leonie Agustina.2014.Sosiolinguistik Pengenalan Awal. Jakarta: Rineka Cipta.

Djajasudarma, Fatimah. T. 1993. Metode Linguistik. Ancangan Metode Penelitian dan Kajian. Bandung: PT.Eresco.

Lapasau, Merry, dan E. Zaenal Arifin. 2016. Sosiolinguistik. Jakarta: Pustaka Mandiri. Masnur Muslich. 2010. Tata Bentuk Babasa Indonesia. Jakarta: Bumi Aksara

Ramlan.2005. Ilmu Babasa Indonesia: Sintaksis.Cetakan Kesembilan. Yogyakarta: C.V Karyono

Suandi,Nengah. 2014. Sosiolinguistik. Yogyakarta: Graha Ilmu. 